\title{
Bio-based synthesis of silver nanoparticles from orange waste: effects of distinct biomolecule coatings on size, morphology, and antimicrobial activity
}

This article was published in the following Dove Press journal: Nanotechnology, Science and Applications

\section{Caio Henrique Nasi de Barros \\ Guilherme Crispim Faria \\ Cruz \\ Willian Mayrink \\ Ljubica Tasic}

Laboratory of Chemical Biology, Department of Organic Chemistry, Instituto de Química da Universidade Estadual de Campinas-Unicamp, Campinas, SP, Brazil
Correspondence: Ljubica Tasic Laboratório de Química Biológica, Departamento de Química Orgânica, Instituto de Química-Universidade Estadual de Campinas, Caixa Postal 6154, Campinas, SP |3083-86|, Brazil

Tel +551935211106

Fax +551935213023

Email ljubica@iqm.unicamp.br
Purpose: Despite the numerous reports on biological syntheses of silver nanoparticles (AgNPs), little is known about the composition of their capping agents, protein corona of plant extractmediated synthesis, and their influence on the properties of AgNPs. Here, orange (Citrus sinensis) waste was utilized as a source of an extract for AgNP synthesis (the protein corona composition of which was elucidated), and also as a starting material for hesperidin and nanocellulose extraction, which were used for bio-based AgNP synthesis. A comparison of the results using the two methods of synthesis is presented.

Methods: AgNPs were synthesized using orange (C. sinensis) peel extract (Or-AgNPs) in a biological route, and using hesperidin (Hsd-AgNPs) and nanocellulose (extracted from oranges) in a green chemical route. Characterization of nanoparticles was carried out using zeta potential and hydrodynamic size measurements, transmission electron microscopy, and X-ray diffraction. Elucidation of proteins from protein corona was performed via ultra performance liquid chromatography-tandem mass spectrometer experiments. Antimicrobial activity was assessed via minimum inhibitory concentration assays against Xanthomonas axonopodis pv. citri (Xac), the bacterium that causes citric canker in oranges.

Results: Or-AgNPs were not completely uniform in morphology, having a size of $48.1 \pm 20.5 \mathrm{~nm}$ and a zeta potential of $-19.0 \pm 0.4 \mathrm{mV}$. Stabilization was performed mainly by three proteins, which were identified by tandem mass spectrometry (MS/MS) experiments. Hsd-AgNPs were smaller $(25.4 \pm 12.5 \mathrm{~nm})$ and had uniform morphology. Nanocellulose provided a strong steric and electrostatic $(-28.2 \pm 1.0 \mathrm{mV})$ stabilization to the nanoparticles. Both AgNPs presented roughly the same activity against $X a c$, with the minimum inhibitory concentration range between 22 and $24 \mu \mathrm{g} \mathrm{mL}^{-1}$. Conclusion: Despite the fact that different capping biomolecules on AgNPs had an influence on morphology, size, and stability of AgNPs, the antibacterial activity against Xac was not sensitive to this parameter. Moreover, three proteins from the protein corona of Or-AgNPs were identified. Keywords: silver nanoparticles, orange peel, Citrus sinensis, Xanthomonas, hesperidin

\section{Introduction}

The fast development of nanomaterials in the quest for green, eco-friendly routes for new products often culminates in the utilization of microorganisms ${ }^{1}$ and plant biomasses for the manufacture of sustainable nanocomposites ${ }^{2,3}$ and nanoparticles, ${ }^{4-6}$ which are frequently used in biological approaches. ${ }^{7}$ In this scenario, the sweet orange (Citrus sinensis) presents various possibilities of biomass utilization since, after juice extraction, the remaining $50 \%$ of the fruit material is composed of peel, albedo, seeds, 
and bagasse. ${ }^{8}$ This biomass is rich in bioflavonoids, insoluble (22.9\%) and soluble fibers (18.6\%), as well as proteins (4\%), ${ }^{9}$ all of which have potential applications in nanobiotechnology, such as in the synthesis of silver nanoparticles (AgNPs).

Many biological routes of AgNPs synthesis have been reported using plant extracts, such as oranges, ${ }^{10,11}$ lemons, ${ }^{12}$ pepper, ${ }^{13}$ red cabbage, ${ }^{14,15}$ Aloe vera,${ }^{16}$ Nigella sativa,${ }^{17}$ Pulicaria glutinosa,${ }^{18}$ Justicia glauca,${ }^{19}$ Mimusops elengi L., ${ }^{20}$ and coffee. ${ }^{21}$ However, in most cases, a deep characterization of the biomolecule coating is not made. It is known that the reducing agents may include flavonoids, membrane proteins, $\mathrm{NAD}(\mathrm{P})^{+}$reductases, dehydrogenases, citric acid, polyphenols, and secondary metabolites, ${ }^{22}$ whereas the capping agents may be extracellular proteins, enzymes, peptides, and tannic acids. ${ }^{23}$ Previous studies by our research group have already elucidated the protein involvement in AgNPs synthesis using fungi, which happens through nitrogen- and sulfur-containing groups, ${ }^{24,25}$ but no reports on protein identification in plant-mediated AgNPs synthesis have been made so far. The protein corona is known to be constituted by a soft corona and a hard corona, which have distinct dissociation constant values. ${ }^{26}$ Moreover, it has a large influence on silver ion release ${ }^{27}$ and nanoparticle internalization, ${ }^{28}$ which are processes intrinsically related with the antibacterial properties of AgNPs. Knowing the composition and properties of the components involved in plant extract-mediated AgNPs syntheses could complement the research field and provide insights into protein corona composition and kinetics, which could lead to a tailored, scaled-up, industry-oriented process.

On the other hand, carbohydrate-stabilized nanoparticles usually involve carboxymethyl polysaccharide ${ }^{29,30}$ and can also be made via biogenic synthesis. ${ }^{31,32}$ Nevertheless, very few reports have been performed on AgNPs stabilized by nanocellulose. ${ }^{33}$ This material can be extracted from various types of biomasses, including oranges, ${ }^{34}$ and presents a great potential as a renewable nanomaterial owing to its sustainability, high versatility (in the form of nanofibrils, nanowhiskers, or nanocrystals), and ease of extraction.

In this paper, orange waste is used to provide distinct capping compositions (protein, nanocellulose) to in situ synthesized AgNPs to evaluate the effects of distinct surfacebound biomolecules on the size, morphology, and antibacterial activity of the nanoparticles. For the biological route, the composition of the protein corona is elucidated. The nanoparticles were assessed regarding their antimicrobial potential against Xanthomonas axonopodis pv. citri (Xac), the bacterium responsible for the citrus canker disease, often observed in oranges. ${ }^{35}$ Xac causes extensive damage to orange production and hence the agricultural economy especially in Brazil, where the citriculture is extremely significant. ${ }^{36}$ Thus, this study aims to show sustainable alternatives of new antimicrobial products based on nanomaterials by utilizing orange waste to produce AgNPs that are active toward a phytopathogen that affects orange plantations.

\section{Materials and methods}

Solvents and silver nitrate were purchased from Labsynth ${ }^{\circledR}$ and the reagents used for the culture media were purchased from Neogen Corporation, except for the ampicillin salt, which was purchased from Sigma-Aldrich.

\section{Preparation of orange peel extract}

Fresh orange peel was collected from local establishments after the juice extraction. The peel was washed with water and cut into small pieces $\left(\sim 0.5 \mathrm{~cm}^{2}\right)$. Fifty gram of fresh orange peel was added to $800 \mathrm{~mL}$ of water in a $1 \mathrm{~L}$ conical flask and heated up to ebullition under vigorous stirring. Once the solution reached boiling point, the heating was ceased and the mixture was filtered by simple filtration to remove coarse pieces of peel. Following this, a second filtration step was performed using an MF-MilliPore ${ }^{\mathrm{TM}}$ membrane filter with $0.22 \mu \mathrm{m}$ pores under vacuum. The resulting pale-yellow solution was then stored at $-20^{\circ} \mathrm{C}$ for up to a week.

\section{Syntheses of AgNPs using orange peel extract}

A solution of $\mathrm{AgNO}_{3} 1 \mathrm{mmol} \mathrm{L}^{-1}$ was prepared and added to the orange peel extract in a ratio of $1: 1(\mathrm{v}: \mathrm{v})$. The resulting solutions were protected from light with aluminum foil and mixed in a platform shaker for $2 \mathrm{~h}$ before resting.

\section{Extraction of hesperidin from orange peel}

The extraction procedure of hesperidin from the orange peel was adapted from the one reported by Ikan. ${ }^{37}$ Orange peel (C. sinensis) was placed in the oven for $16 \mathrm{~h}$ at $60^{\circ} \mathrm{C}$ and consequently $\sim 50 \mathrm{~g}$ of dry peel was inserted in a Soxhlet extractor. Diethyl ether $(250 \mathrm{~mL})$ was used for extraction during $1.5 \mathrm{~h}$ to eliminate undesirable products such as essential oils. Then, methanol $(250 \mathrm{~mL})$ was used for extraction during $4 \mathrm{~h}$. The methanol solution was cooled and evaporated under vacuum, yielding a thick brownish liquid. To this viscous liquid, $50 \mathrm{~mL}$ of $6 \%$ acetic acid was added under stirring. An orange-yellow precipitate became visible, which was separated from the solution using a Büchner funnel under vacuum. The solid was dried for $2 \mathrm{~h}$ at $60^{\circ} \mathrm{C}$ and allowed 
to cool to the room temperature before weighting. For the recrystallization step, dimethyl sulfoxide was used to make a 20\% (w:v) solution of hesperidin. The same volume of distilled water was added carefully under stirring; then, the formation of pale-yellow crystals was visible. The solution was left at $4^{\circ} \mathrm{C}$ for several hours allowing crystallization to occur, followed by centrifugation for $5 \mathrm{~min}$ at $5000 \mathrm{rpm}$, washing with cold distilled water and drying under vacuum in a Büchner funnel resulting in pale-yellow pure crystals of hesperidin. The solid was dried for $2 \mathrm{~h}$ at $60^{\circ} \mathrm{C}$, cooled to room temperature, and weighted.

\section{Extraction of nanocellulose from orange bagasse}

Industrial orange bagasse was stirred in boiling $\mathrm{HCl} 0.05 \mathrm{~mol}$ $\mathrm{L}^{-1}$ for $1 \mathrm{~h}(17 \mathrm{~g}$ for $50 \mathrm{~mL})$ to remove pectin. The solid was isolated by filtration, washed with water, and then hydrolyzed for $20 \mathrm{~min}$ in a $\mathrm{NaOH} 3 \%$ solution at $1 \mathrm{~atm}$ and $120^{\circ} \mathrm{C}$ in an autoclave. The solid was bleached twice with $\mathrm{NaClO}_{2} 3 \%$ at $70^{\circ} \mathrm{C}, \mathrm{pH} 4.5$ for $30 \mathrm{~min}$ and the solid was filtered, washed with hot water, and dried under vacuum in a Büchner funnel. An aqueous suspension of microfibrillated cellulose was sonicated for $5 \mathrm{~min}$ in an ultrasonic processor with a tip for complete dispersion of the solid, yielding a suspension of nanofibrillated cellulose.

\section{Syntheses of AgNPs using hesperidin and nanocellulose}

This procedure was adapted from the one described by Lokanathan et al. ${ }^{33} \mathrm{~A}$ solution containing equal volumes of $\mathrm{AgNO}_{3}\left(1 \mathrm{mmol} \mathrm{L}^{-1}\right)$ and nanocellulose extracted from orange bagasse $(0.01 \%)$ was sonicated in a sonication bath for $15 \mathrm{~min}$ and filtered using a $0.22 \mu \mathrm{m}$ pore sized filter to eliminate macroscopic particles. Then, a solution of $2.0 \mathrm{mg}$ $\mathrm{mL}^{-1}$ hesperidin in $\mathrm{NaOH}\left(0.1 \mathrm{~mol} \mathrm{~L}^{-1}\right)$ extracted from orange peel was added to the silver salt solution dropwise under stirring. The proportion used for silver nitrate, nanocellulose, and hesperidin solutions was 2:2:1 (v:v:v). An orange color appeared after a few minutes, indicating formation of nanoparticles. Once the formation was complete, nanoparticles were washed by ultracentrifugation at $14,000 \mathrm{rpm}$ for 30 min and suspended in water. This procedure lowered the $\mathrm{pH}$ to neutral and eliminated residual hesperidin from the solution.

\section{Characterization techniques UV-visible spectroscopy}

All spectra were obtained using a UV-vis HP8453 spectrophotometer from solutions placed in quartz cuvettes with a path length of $10 \mathrm{~mm}$. The spectra were taken in the range from 300 to $700 \mathrm{~nm}$. The blank solutions were always prepared using the same reagents but substituting the silver nitrate solution for distilled water. For the kinetic studies, a Peltier Temperature Controller was coupled to the spectrometer in order to maintain the temperature at $25^{\circ} \mathrm{C}$ over $48 \mathrm{~h}$ with one spectrum/30 min (orange peel extract AgNPs) or over $2 \mathrm{~h}$ with one spectrum/5 min (hesperidin/nanocellulose AgNPs).

\section{Infrared spectroscopy}

Spectra were obtained in an Agilent CARY 630 Fouriertransformed infrared (FTIR) spectrophotometer, from 4000 to $400 \mathrm{~cm}^{-1}, 64$ scans, and a resolution of $4 \mathrm{~cm}^{-1}$. Orange peel extract and the corresponding AgNPs suspensions were previously lyophilized. Before freeze-drying, the AgNPs suspension was centrifuged three times at $5000 \mathrm{rpm}$ for 30 min, removing the supernatant every time and redissolving the precipitated nanoparticles in half of the original volume. This procedure was necessary to remove biomolecules that were not attached to AgNPs and that could mask relevant bands in the spectrum.

\section{Raman scattering}

A Horiba T64000 Raman spectrometer was used for the analyses with the $632.8 \mathrm{~nm}$ laser in the range from 100 to 900 $\mathrm{cm}^{-1}$. A Micro Raman XploRa was used to obtain spectra with the $785 \mathrm{~nm}$ laser between 100 and $4000 \mathrm{~cm}^{-1}$. A sample of orange peel extract AgNPs was freeze-dried prior to analysis.

\section{Zeta potential and dynamic light scattering}

All the data were acquired in a Zetasizer Nano ZS (Malvern Instruments Corp., Malvern, UK) analyzer. Both Zeta potential and size measurements were made at $25^{\circ} \mathrm{C}$ using a disposable folded capillary cell DTS1070 and running three manual measurements with 15 scans each.

\section{X-ray diffraction}

The analyses were performed in a DRX7000 Shimadzu using a copper target with $\mathrm{K} \alpha=1.54 \AA, 40 \mathrm{kV}, 30 \mathrm{~mA}$, in a range covering from $2 \theta=30^{\circ}$ to $80^{\circ}$, with a rate of $2^{\circ}$ per minute The samples were previously lyophilized.

\section{Transmission electron microscopy}

AgNPs suspensions were diluted in deionized water 1:3 (v:v) and then dried overnight on the sample holder. Analyses were carried out in a Carl-Zeiss Libra 120 microscope using $\mathrm{HV}=80 \mathrm{kV}$. Particle counting was done with ImageJ software (National Institutes of Health). 


\section{Inductively coupled plasma optical emission spectroscopy}

This technique was utilized to assess the yield of the AgNPs syntheses. Samples of both types of AgNPs, washed (centrifugation at $14,000 \mathrm{rpm}$ for $30 \mathrm{~min}$ at $25^{\circ} \mathrm{C}$; dispersion in distilled water) and unwashed, were used. A measured quantity of $500 \mu \mathrm{L}$ of the sample was digested with $500 \mu \mathrm{L}$ of $\mathrm{HNO}_{3}$ (conc.) for $16 \mathrm{~h}$ period. Then, each solution was diluted to $10.0 \mathrm{~mL}$ with ultrapure water, and the concentration of silver ions was detected using Perkin Elmer-Optima 8300 equipment. The calibration curve was made using an $\mathrm{Ag}$ standard solution in $2 \%-5 \% \mathrm{HNO}_{3}$. The yield of the process was calculated as the ratio between the quantity of silver detected in the washed samples and the quantity of silver in the unwashed samples.

\section{Mass spectrometry}

This procedure was optimized from the one described by Aragão et al. ${ }^{38}$ The orange peel extract AgNPs suspension (Or-AgNPs) was first washed by ultracentrifugation $\left(14,000 \mathrm{rpm}, 30 \mathrm{~min}, 25^{\circ} \mathrm{C}\right)$ and redispersed in $1 / 10$ of the original volume to remove unbound proteins. Digestion was carried out using a standard protocol using trypsin enzyme (Sequencing Grade Modified Trypsin, Promega). Isolation of peptides was then performed using a standard procedure for solid phase extraction using acetonitrile (1\% formic acid). The resulting solution was then concentrated by vacuum centrifugation and solubilized in $8 \mu \mathrm{L}$ of water containing $1 \%$ formic acid prior to ultra performance liquid chromatography-tandem mass spectrometer (UPLC-MS/ MS) analysis. An aliquot of $4.5 \mu \mathrm{L}$ of proteins resulting from peptide digestion was separated by C18 (100 and $6100 \mathrm{~mm}$ ) RP-nanoUPLC (nanoAcquity, Waters) coupled with a Q-Tof Premier mass spectrometer (Waters) with a nanoelectrospray source at a flow rate of $0.6 \mathrm{~mL} \mathrm{~min}^{-1}$. The gradient was $2 \%-90 \%$ acetonitrile in $0.1 \%$ formic acid over $90 \mathrm{~min}$. The nanoelectrospray voltage was set to $3.5 \mathrm{kV}$, with a cone voltage of $30 \mathrm{~V}$, and the source temperature was $100^{\circ} \mathrm{C}$. The instrument was operated in the "top three" mode, in which one MS spectrum is acquired followed by MS/MS of the top three most-intense peaks detected. After MS/MS fragmentation, the ion was placed on exclusion list for $60 \mathrm{~s}$. For data analysis, the spectra were acquired using software MassLynx v.4.1 and the raw data files were converted to a peak list format (mgf) without summing the scans by the software Mascot Distiller v.2.3.2.0, 2009 (Matrix Science Ltd.) and searched against the database C. sinensis 2017 (88,146 sequences, 36,207,566 residues) using Mascot engine v.2.3.01 (Matrix Science Ltd.), with carbamidomethylation as fixed modifications, oxidation of methionine as variable modification; one trypsin missed cleavage and a tolerance of $0.1 \mathrm{Da}$ for both precursor and fragment ions.

\section{Bioinformatics}

The server I-TASSER was used for protein structure prediction, followed by RasMol (v. 2.5.7.2.) for protein modeling. The metaserver $\mathrm{COACH}$ was used for function prediction, and BLAST (Basic Local Alignment Search Tool-National Center for Biotechnology Information) was utilized for sequence alignments.

\section{Bacterial culture}

Strain 306 of Xanthomonas axonopodis pv. citri (Xac) was cultivated in solid culture medium containing $5 \mathrm{~g} \mathrm{~L}^{-1}$ yeast extract, $10 \mathrm{~g} \mathrm{~L}^{-1}$ peptone $\mathrm{G}$, and $15 \mathrm{~g} \mathrm{~L}^{-1}$ agar. The culture medium was sterilized in an autoclave for $15 \mathrm{~min}$ at $1 \mathrm{~atm}$ and $120^{\circ} \mathrm{C}$ and ampicillin was added in a water:ethanol $(1: 1, \mathrm{v}: \mathrm{v})$ solution so that the final concentration would be $50 \mu \mathrm{g} \mathrm{mL}$. After inoculation, the agar plate was incubated at $35^{\circ} \mathrm{C}$ for $24 \mathrm{~h}$. A liquid culture medium $(100 \mathrm{~mL})$ was prepared using the same compounds (excluding agar) in which one isolated colony from the solid bacterial culture was introduced. The liquid culture was grown over $20 \mathrm{~h}$ at $200 \mathrm{rpm}$ and $32^{\circ} \mathrm{C}$ in an orbital shaker.

\section{MIC assay}

The overnight culture, whose absorbance at $600 \mathrm{~nm}\left(\mathrm{~A}_{600}\right)$ was measured, was diluted to $0.1\left(\sim 10^{8}-10^{10} \mathrm{CFU} \mathrm{mL} \mathrm{mL}^{-1}\right)$ using sterile $\mathrm{NaCl}(0.9 \%)$ solution. The culture medium containing antibiotic (without inoculum) was also used, as well as the stock AgNPs suspensions. Using a 96-well plate, dilutions of the AgNPs stock suspension were made using the sterile culture medium $(50,40,30,25,20,25$, 10,5 , and $1 \mu \mathrm{g} \mathrm{mL}^{-1}$ ) in such way that the final volume would be $200 \mu \mathrm{L}$, with the posterior addition of $50 \mu \mathrm{L}$ of the inoculum suspension. Moreover, a positive control (100 $\mu \mathrm{L}$ inoculum $+100 \mu \mathrm{L}$ sterile culture medium) and a negative control ( $100 \mu \mathrm{L}$ inoculum $+100 \mu \mathrm{L}$ AgNPs suspension) were also prepared. All the wells of every row were used for the same AgNPs concentration or purpose, and the procedure was done in triplicate. The plates were incubated at $35^{\circ} \mathrm{C}$ for $48 \mathrm{~h}$, and then the reading was performed both by visual verification of turbidity and by a 96-well plate absorbance reader (Molecular Devices SpectraMax ${ }^{\circledR}$ M2; Figure S1). Following completion of this process, a second round of 
minimum inhibitory concentration (MIC) assays was performed expanding a small AgNPs concentration range that comprises the MIC in order to obtain a better accuracy of these values.

\section{Results and discussion \\ Bio-based syntheses using citrus waste and AgNPs characterization}

AgNPs were synthesized using aqueous orange (C. sinensis) peel extract mixed with a silver nitrate solution (Or-AgNPs) (Figure 1). The pale-yellowish extract started changing to an orange-yellow color as the reaction proceeded and ultimately turned to a dark-orange color after $\sim 5 \mathrm{~h}$ (Figure 1A). The reaction was monitored by UV-Vis spectroscopy over the course of $48 \mathrm{~h}$ in order to study the kinetics of the reac-

A

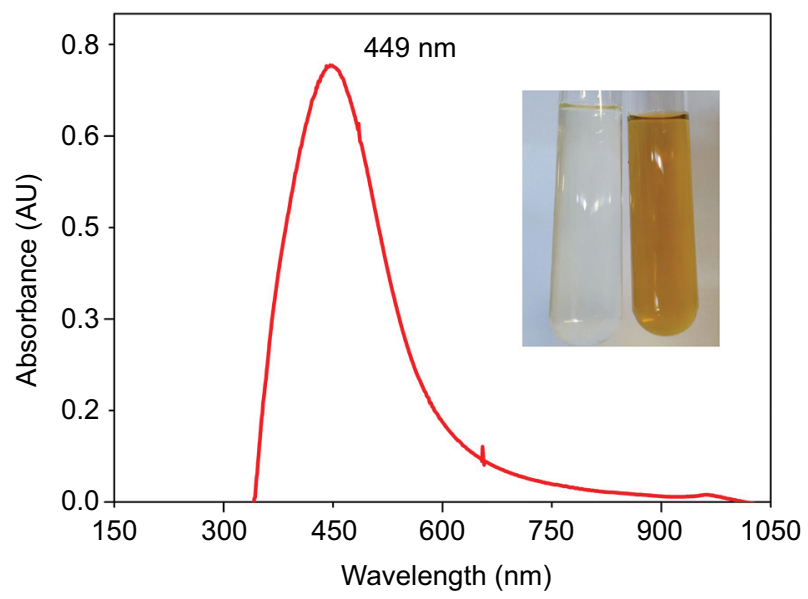

C

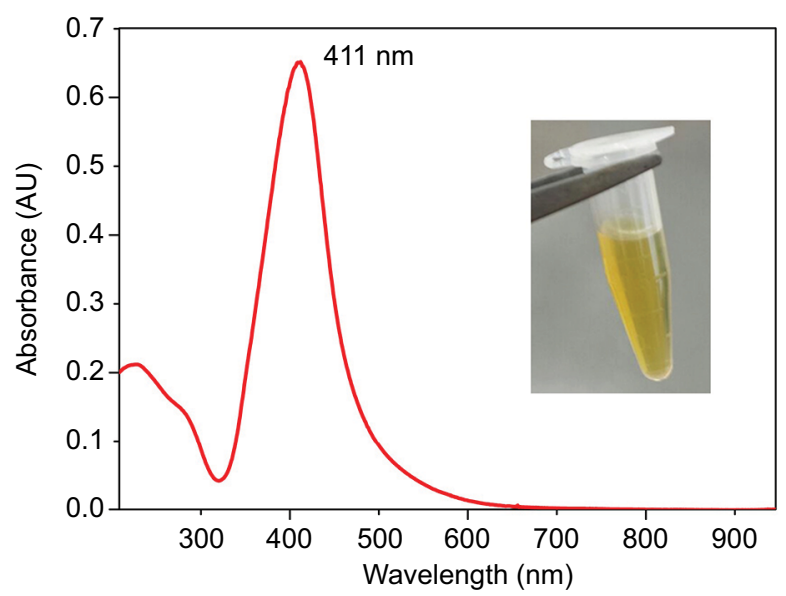

tion (Figure 1B). The surface plasmon resonance (SPR) absorption band was shifted from 430 to $449 \mathrm{~nm}$ over the course of $48 \mathrm{~h}$, suggesting that nanoparticles grew in size during this period. The nanoparticle formation was fastest during the first $5 \mathrm{~h}$ of the reaction, and then became gradually slower (Figure 1C). The reaction was performed at room temperature, as a temperature higher than $30^{\circ} \mathrm{C}$ was shown to induce fast formation and aggregation of nanoparticles (as seen in preliminary tests). The $\mathrm{pH}$ of the orange extract (usually situated between 4 and 5) is optimal for the synthesis, as values of $\mathrm{pH}$ above 7 also induce aggregation, easily seen with a color change. Similarly, preliminary tests showed that a more concentrated extract as well as a more concentrated silver salt solution leads to nanoparticle coalescence.
B

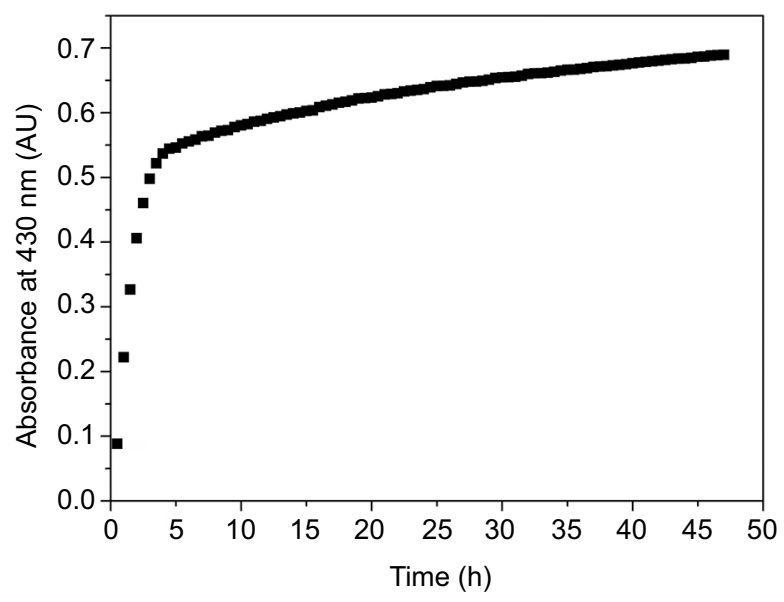

D

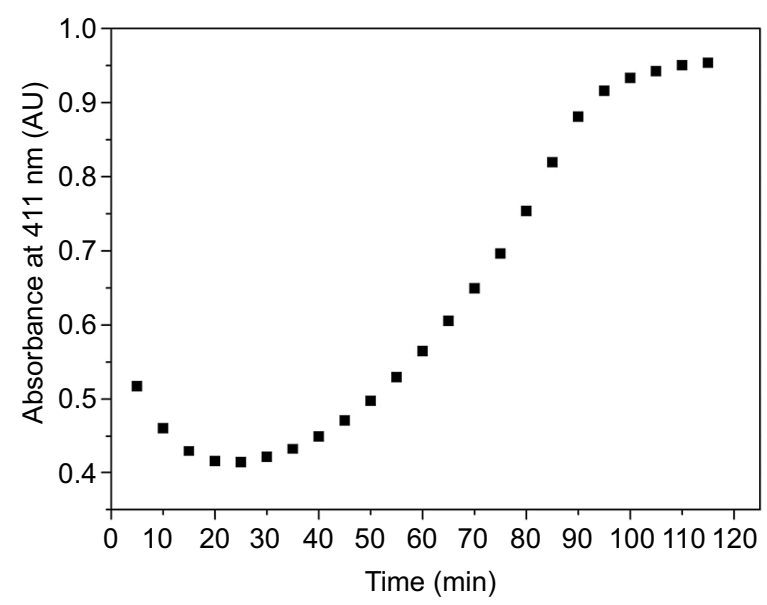

Figure I UV-Vis absorption spectrum of Or-AgNPs after $48 \mathrm{~h}$ of reaction displaying the characteristic surface plasmon resonance band at $449 \mathrm{~nm}$. In detail, the photographic image of the extract (left) and the corresponding AgNPs suspension (right) (A). The kinetic progression of the Or-AgNPs reaction during the $48 \mathrm{~h}$ monitored setting the absorbance at $430 \mathrm{~nm}$ (B). UV-Vis absorption spectrum of Hsd-AgNPs after $2 \mathrm{~h}$ of reaction displaying the characteristic surface plasmon resonance band at $4 \mathrm{II} \mathrm{nm}$. In detail, the photographic image of the AgNPs suspension (C). The kinetic progression of the Hsd-AgNPs reaction during the $2 \mathrm{~h}$ monitored setting the absorbance at $4 \mathrm{I} \mathrm{I}$ nm (D). Abbreviations: AgNPs, silver nanoparticles; AU, arbitrary unit; Hsd, hesperidin; Or, aqueous orange; UV-vis, ultraviolet-visible. 
Hesperidin had been used as a suitable reduction agent for the production of gold $^{39}$ and silver nanoparticles. ${ }^{40,41}$ Here, AgNPs synthesized via reduction with hesperidin and stabilized with nanocellulose (Hsd-AgNPs) were produced within $2 \mathrm{~h}$ in alkali medium (Figure 1D; Figure S2), and yielded a clear yellow suspension with SPR band located at $411 \mathrm{~nm}$ (Figure 1C), with no significant shifts. This reaction was more sensitive to the silver salt and hesperidin concentrations, as it occurred more quickly when compared with the extract-mediated synthesis. The $\mathrm{pH}$ was around 12.0, as the hesperidin molecule needed to be deprotonated in order to be soluble in water. High temperature $\left(>30^{\circ} \mathrm{C}\right)$ was again shown as a factor that induces aggregation.

The size distributions of the nanoparticles were first determined using dynamic light scattering (DLS). For OrAgNPs, DLS analysis showed nanoparticles with an average hydrodynamic diameter of $239 \pm 1 \mathrm{~nm}$, with a polydispersity (PdI) of 0.287, while for Hsd-AgNPs, the mean diameter calculated was significantly smaller $(100 \pm 39 \mathrm{~nm})$. The zeta potential of dispersion refers to the electrostatic voltage at the shear layer of a nanoparticle. In this AgNPs system, the zeta potential for Or-AgNPs was $-19.0 \pm 0.4 \mathrm{mV}$. Usually, a colloid system would be considered electrostatically stable when its zeta potential values are above $+30 \mathrm{mV}$ or below $-30 \mathrm{mV}$. In this case, the dispersion was stable for over 3 months as the stabilization involved not only electrostatic interactions, but also steric hindrance provided by biomolecules that interacted with the nanoparticles acting as physical barriers that avoid the coalescence and aggregation of the nanoparticles. In the case of Hsd-AgNPs, the zeta potential of $-28.2 \pm 1.0$ $\mathrm{mV}$ indicates a rather strong electrostatic stabilization possibly caused by negative charges located in the nanocellulose layer. The nanocellulose is also a physical barrier that avoids coalescence, maintaining the system stable for over a year.

Both types of nanoparticles had their yields determined by inductively coupled plasma optical emission spectroscopy quantification. The chemical synthesis of Hsd-AgNPs had a slightly superior silver conversion when compared with Or-AgNPs ( $99 \%$ and $83 \%$, respectively). This result is somewhat expected as the chemical route allows the addition of the reducing agent in excess, whereas the biological route does not permit a proper estimation of the concentration of reducing agents (without a prior analysis, using liquid chromatography, for instance), and therefore, it is not possible to purposely induce complete conversion of silver ions to elemental silver at the moment of the reaction setup.

The X-ray diffraction spectra of Or-AgNPs and Hsd-AgNPs were obtained as seen in Figure $2 \mathrm{~A}-\mathrm{F}$. The strongest peak at $38.1^{\circ}$ refers to the (111) plane of the lattice. The peaks at $44.4^{\circ}$, $64.6^{\circ}$, and $77.4^{\circ}$ correspond to the (200), (220), and (311) planes, respectively. This pattern confirms the face-centered cubic lattice, typical for AgNPs in both cases. ${ }^{42}$ Despite the fact that in several biogenic AgNPs syntheses there is a concomitant formation of $\mathrm{AgCl}$ nanoparticles, ${ }^{43}$ the diffraction pattern did not show data of $\mathrm{Ag} / \mathrm{AgCl}$ nanoparticle system. ${ }^{44}$

The AgNPs were also analyzed under the Transmission Electronic Microscope (Figure S2 and Figure 2B, C, E, F), and it was observed that the average metallic diameter of the nanoparticles was significantly smaller when compared with the hydrodynamic diameter obtained by DLS: $48.1 \pm 20.5$ $\mathrm{nm}$ for Or-AgNPs and $25.4 \pm 12.5 \mathrm{~nm}$ for Hsd-AgNPs. The morphology of Or-AgNPs is not well defined, which can be explained by the multiple reduction routes that silver ions can find in a rich solution containing various reducing agents, such as ascorbic acid, fumaric acid, citric acid, as well as the antioxidant flavonoids hesperidin, naringin, and diosmin. On the other hand, the green chemical route using only hesperidin and nanocellulose yielded spherical, smaller nanoparticles, with a higher control of the morphology.

The process of stabilizing AgNPs leads to the fact that electron-rich elements such as nitrogen, sulfur, and even oxygen establish a chemical bond with the silver atoms. Distinct organic capping may result in distinct forms of interaction of the nanoparticle surface. In Figure 3A, the absorption band at $1598 \mathrm{~cm}^{-1}$ in the extract FTIR spectrum is shifted to $1637 \mathrm{~cm}^{-1}$ upon nanoparticles formation. This band can be assigned as the amide I band, which corresponds to the $\mathrm{C}=\mathrm{O}$ stretching and is usually set around 1650 $\mathrm{cm}^{-1}$ and is highly influenced by the secondary structure of the protein. ${ }^{45}$ The amide III band, which relates to the in-phase coupling of $\mathrm{N}-\mathrm{H}$ bending and $\mathrm{C}-\mathrm{N}$ stretching, is a broad region $\left(1400-1200 \mathrm{~cm}^{-1}\right)$ that is also intrinsically related to the secondary structure of proteins. In the extract spectrum, the amide III band is set at $1259 \mathrm{~cm}^{-1}$, which is then shifted to $1243 \mathrm{~cm}^{-1}$ with AgNPs formation. This highlights that the nitrogen atom may be involved in the AgNPs stabilization, since the electron donation from it to silver atoms would preclude the classic amide resonance. A decrease in bond strength could then lead to a shift to smaller wavenumbers. These data suggest that the biomolecule coating that stabilizes biogenic Or-AgNPs may interact with the silver atoms through nitrogen atoms coming from amide bonds, which are most probably present in proteins.

Conversely, the green chemical synthesis of Hsd-AgNPs resulted in a completely different infrared absorption 
A

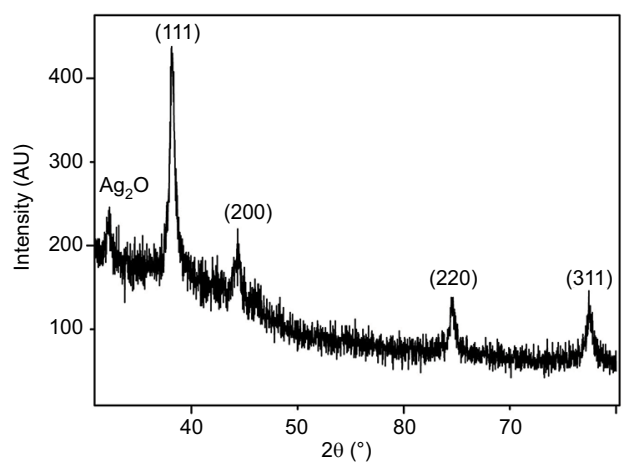

D

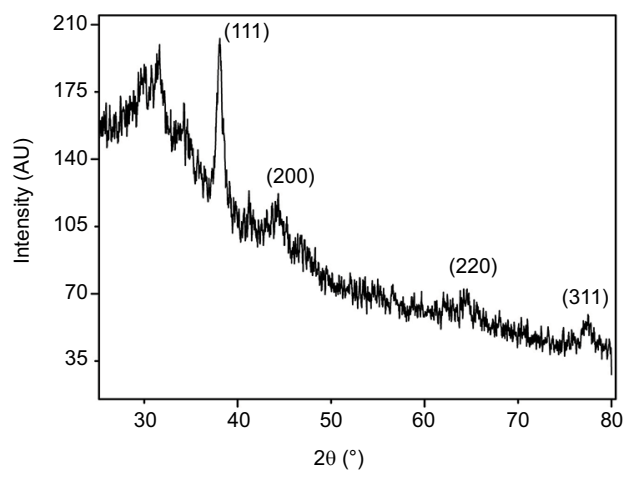

B

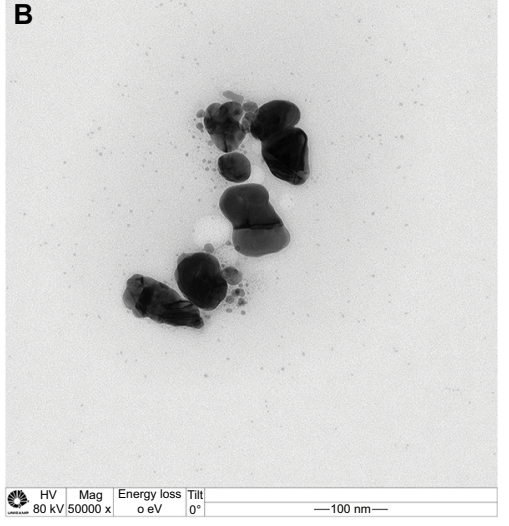

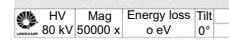

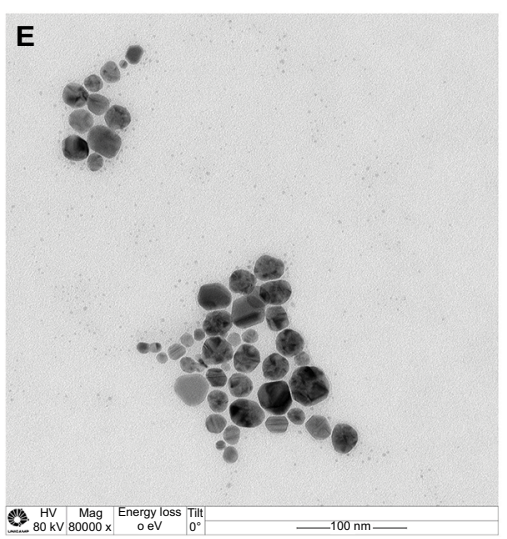

C
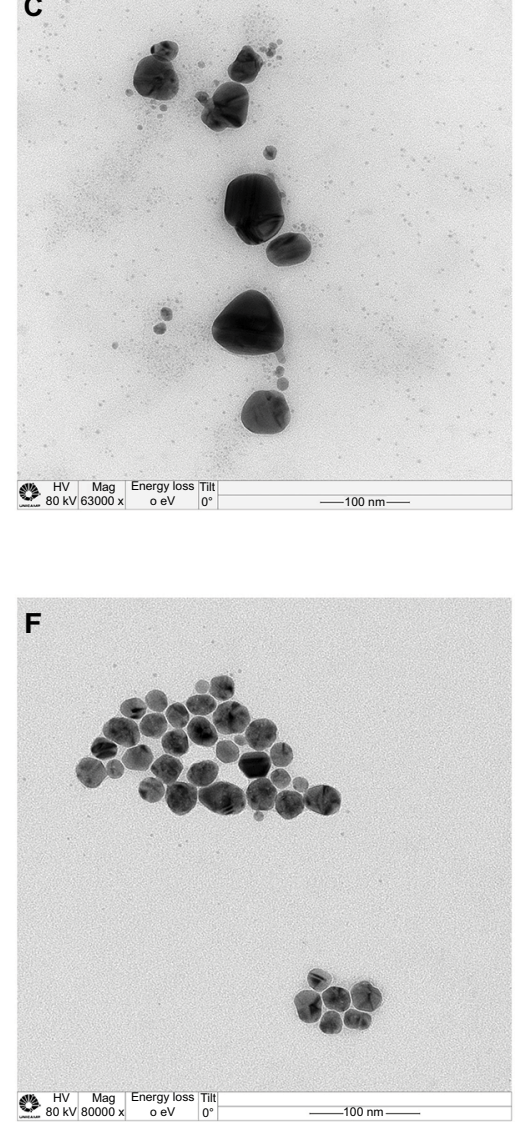

Figure 2 X-ray diffraction pattern of orange peel extract AgNPs (A); images of orange peel extract AgNPs obtained by TEM (B and C); X-ray diffraction pattern of hesperidin/nanocellulose AgNPs (D); images of hesperidin/nanocellulose AgNPs obtained by TEM (E and F).

Abbreviations: AgNPs, silver nanoparticles; AU, arbitrary unit; TEM, transmission electron microscopy.

spectrum (Figure 3B). The split band typical of the carbonyl group from the hesperidin structure found at 1647 and $1606 \mathrm{~cm}^{-1}$ is not present in the Hsd-AgNPs, confirming the chemical reaction. The nanocellulose spectrum displays $\mathrm{C}-\mathrm{O}$ stretching band at $1021 \mathrm{~cm}^{-1}$, which is shifted to $1034 \mathrm{~cm}^{-1}$ after Hsd-AgNPs formation, which could suggest an interaction between the cellulose chains with the metallic surface.

It is already well known that in biological media, nanoparticles eventually accumulate proteins on their surface forming what is called a protein corona. In biological synthetic routes of AgNPs formation, proteins have also been assigned as main stabilizers of the nanoparticles. However, there is lack of reports on protein corona formation in AgNPs synthesis using plant extracts. Considering that oranges have a rather high content of proteins in their constitution, a deeper analysis was made regarding not only the mode of interaction but also the identity of some proteins involved in Or-AgNPs stabilization.

Raman spectra using 632.8 and $785 \mathrm{~nm}$ lasers were obtained in analyses using a freeze-dried Or-AgNPs suspension. In Figure 4A, an intense peak is seen at $231 \mathrm{~cm}^{-1}$, which is related to the $\mathrm{Ag}-\mathrm{S}$ bond, suggesting that thiol groups coming from cysteine residues may be linked to the stabilization of the AgNPs dispersion. A weak broad region between 655 and $700 \mathrm{~cm}^{-1}$ contains the band corresponding to $\mathrm{C}-\mathrm{S}$ stretching, in this case associated with cysteine residues. ${ }^{46,47} \mathrm{~A}$ weak band at $1285 \mathrm{~cm}^{-1}$ (Figure 4B) can be related to an amide III band, whereas the sharp band over $587 \mathrm{~cm}^{-1}$ has its closest assignment to a disulfide $\mathrm{S}-\mathrm{S}$ bond deformation, even though this vibration usually appears in a lower wavenumber range (499 to $\left.553 \mathrm{~cm}^{-1}\right){ }^{48}$

In order to identify which proteins are bound to the nanoparticles surface, UPLC-MS/MS analysis was carried out. Three proteins were identified via detection of main fragments and matching with MASCOT server, followed by protein structure prediction using the I-TASSER server (Figure 5). None of them have yet been characterized empirically; one is hypothetical and the other two have been assigned to predicted functions. The molecular masses varied from 10 to $39 \mathrm{kDa}$, and all the three proteins are rich in cysteine residues, which contributes to the hypothesis of interaction via sulfur-containing groups. 
A

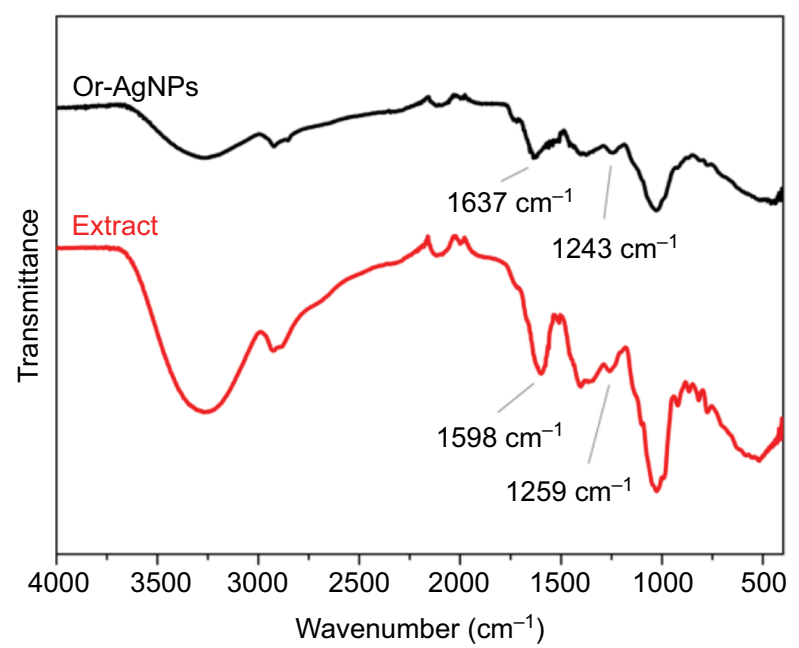

B

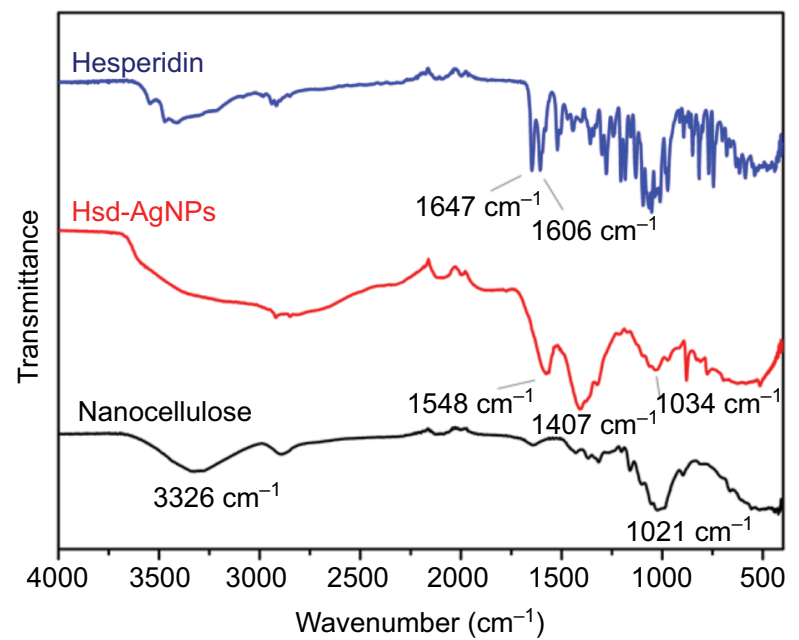

Figure 3 Comparison of FTIR spectra of freeze-dried samples of orange peel extract and Or-AgNPs (A) and Hsd-AgNPs (B).

Abbreviations: $\mathrm{AgNPs}$, silver nanoparticles; $\mathrm{AU}$, arbitrary unit; FTIR, Fouriertransformed infrared spectroscopy; Hsd, hesperidin; Or, aqueous orange.

The gene germin-like protein (Accession number XP_006479011.1) is known for having oxalate oxidase activity in plants and is traditionally linked to plant development. Currently, this protein superfamily is also linked to disease resistance, as it is responsible for the conversion of oxalic acid into $\mathrm{H}_{2} \mathrm{O}_{2}$ and $\mathrm{CO}_{2}$. Hydrogen peroxide has the function of mediating cross-link reactions in the cell wall, reinforcing its structure. ${ }^{49}$ However, a study has revealed that the coding gene of germin-like protein in C. sinensis is downregulated in plants infected with Xylella fastidiosa, which could lead to reduction in growth and development. ${ }^{50}$

The predicted homolog protein IN2-1 B-like (Accession number XP_006471422.1) has a large identity (99\%) and coverage (88\%) when compared with glutathione

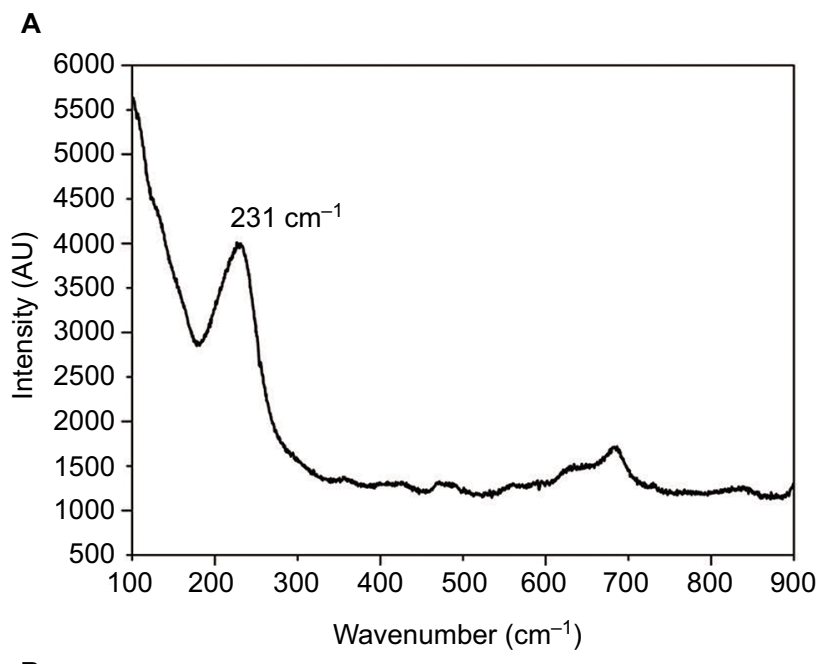

B

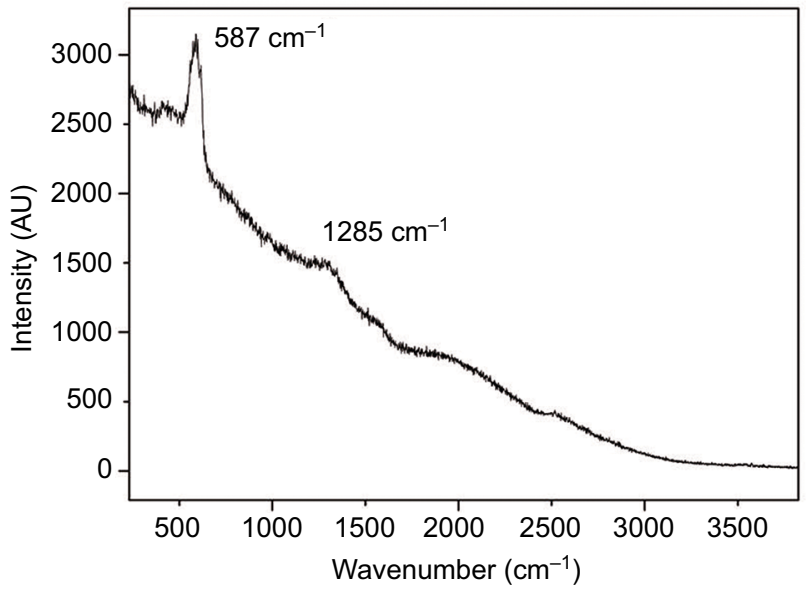

Figure 4 Raman scattering spectra of Or-AgNPs suspension using $632.8 \mathrm{~nm}$ laser (A) and $785 \mathrm{~nm}$ laser (B).

Abbreviation: AgNPs, silver nanoparticles; Or, aqueous orange.

$S$-transferase L3-like protein. The function prediction performed by the $\mathrm{COACH}$ metaserver also indicates glutathione as the most probable ligand of this protein. In plants, the glutathione $S$-transferase is the enzyme responsible for the conjugation of glutathione with electrophilic xenobiotics, thus being associated with plant defense against diseases as the expression levels of glutathione $S$-transferase raises significantly after exposure to stress. ${ }^{51}$ Lo Piero et al isolated cDNA and genomic clones of glutathione $S$-transferases from C. sinensis L. Osbeck, suggesting the most probable role of vacuolar import of anthocyanin. ${ }^{52}$

The hypothetical protein CISIN_1g014537 (Accession number KDO42750.1) also had its function predicted by the $\mathrm{COACH}$ metaserver, following molecular structure prediction. The highest similarity template protein is an aspartic-type endopeptidase (PDB entry: 1OD1A), which is a common protein type found in plants. This enzyme is a protease with an aspartate residue in the binding site that binds 


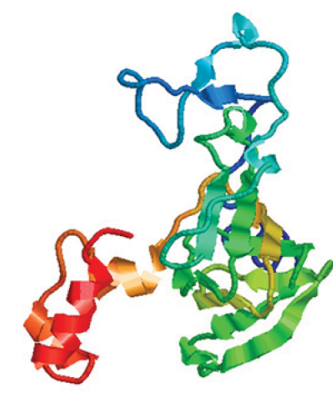

Predicted: Germin-like protein subfamily 1 member 17 (Citrus sinensis)

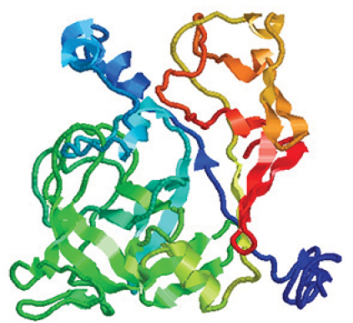

Hypothetical protein CISIN_1g014537 (Citrus sinensis)

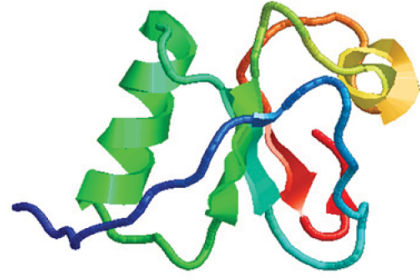

Predicted: Homolog protein IN2-1 B-like (Citrus sinensis)

Figure 5 Proteins identified as capping agents in Or-AgNPs in UPLC-MS/MS experiments, with tridimensional structures predicted by I-TASSER server. Abbreviations: AgNPs, silver nanoparticles; Or, aqueous orange; UPLC-MS/MS, ultra performance liquid chromatography-tandem mass spectrometer.

to an activated water molecule, promoting the hydrolysis of a peptide chain in acidic environment. ${ }^{53}$ Its tertiary structure comprises mostly $\beta$-strands and low $\alpha$-helix content. ${ }^{54}$ Not much is known about the biological functions of this enzyme, although some studies have suggested protein degradation and viral polyprotein processing. ${ }^{55}$ However, in citrus plants, this enzyme type has been assigned to the proteolysis of ribulose-1,5-biphosphate carboxylase/oxygenase, which is a protein known for nitrogen storage in plants during growth stages of new organs. ${ }^{56}$

\section{Minimum inhibitory concentration assay}

There are many possible explanations for the antimicrobial activity of AgNPs, all of which can contribute to the antimicrobial action. ${ }^{57}$ Le Ouay and Stellacci ${ }^{58}$ state that there are two steps in the mode of action of AgNPs. The first step comprises the physical and chemical modifications that occur in the system that affect the metal availability, whereas the second step is related to the actual interactions that take place between AgNPs and the bacterial cell. Regarding the first step, in interactions where proteins (Or-AgNPs) or carbohydrates (Hsd-AgNPs) are involved, the preexistence of capping agents avoids the attachment of new biomolecules present in the medium directly onto the nanoparticles' surface. However, protein-protein, protein-peptide, carbohydrate-protein, and carbohydrate-peptide interactions may occur via adsorption, modifying the original biomolecules capping. ${ }^{59}$ The newly formed corona is then the portion of the nanoparticle complex that gets in contact with the bacterial cells. The second step involving the actual interactions between the metal and the bacterial surface is highly dependent on the bacterium Gram type. Xac is a Gram-negative bacterium and therefore possesses an outer membrane that is lacking in Gram-positive bacteria. This outer membrane is crucial in the selective permeability of the cell. Studies have shown that in the presence of AgNPs, Gram-negative bacteria have their outer membrane selectivity modified, with the subsequent intake of AgNPs that could then interfere with enzymes involved in the respiratory chain of the cell. ${ }^{60}$ Additionally, AgNPs may cause the appearance of "pits" on the cell membrane and accumulation on its surface. ${ }^{61}$ Another possible mechanism involves the release of silver ions; Feng et $\mathrm{al}^{62}$ state that the presence of these ions on the bacterial cell wall surface shrank or detached the membrane from the cell wall and they invaded the cell. Moreover, silver ions can either interact with thiol groups from proteins, inactivating them, or can interact with DNA, arresting its replication ability. However, in the presence of biomolecule capping, this mechanism is hindered by the interaction between the newly released silver ions and the capping agents. ${ }^{27}$ 
In this case, both types of AgNPs were able to inhibit Xac growth in low concentrations: $22 \pm 2 \mu \mathrm{g} \mathrm{mL}{ }^{-1}$ for Or-AgNPs and $24 \pm 2 \mu \mathrm{g} \mathrm{mL}^{-1}$ for Hsd-AgNPs. The very similar values of MICs reveal that the biomolecule coating has little to no effect on the bacteriostatic effect. Both the nanoparticles stabilized mainly by proteins (Or-AgNPs) and nanocellulose (Hsd-AgNPs) have similar actions, even when considering the smaller size of Hsd-AgNPs. Previous studies of the group ${ }^{24,25}$ have already reported on the biosynthesis of AgNPs from fungi and MIC value against Xac, which was lower (6.55 \pm 0.22 $\mu \mathrm{g} \mathrm{mL}^{-1}$ ) compared with the AgNPs reported here. The bacterium Xanthomonas perforans, which affects tomato crops, was also shown to be susceptible to silver in the form of a silver-DNA-graphene oxide nanocomposite (Ag@dsDNA@ GO) at 100 ppm during in vivo assays. ${ }^{63,64}$ It is worth noting that, despite the fact the orange extracts are known for containing antibacterial compounds themselves, ${ }^{65-67}$ this extract was unable to inhibit Xac growth in MIC assays mimicking the same conditions used for the AgNP suspensions.

\section{Conclusion}

Although the Or-AgNPs have a rather simple synthetic procedure and are more environmental friendly, the reaction is not easy to be controlled due to the existence of many biomolecules in solution that can interfere in the synthesis, which leads to an average reproducibility. On the other hand, Hsd-AgNPs are more laborious to produce (having seen all the extraction steps for both hesperidin and nanocellulose), but the nanoparticles are smaller and more homogeneous in size range and shape, with a higher electrostatic stabilization.

Or-AgNPs are stabilized by proteins which were identified by MS/MS experiments, being one germin-like protein with oxalate oxidase activity, one protein with glutathione $S$-transferase function, and a hypothetical protein assigned to aspartictype endopeptidase structure and function. These proteins interact with AgNPs surface mainly by nitrogen-containing (as seen through FTIR experiments) and sulfur-containing (as seen through Raman scattering experiments) groups.

The antibacterial activity of both types of AgNPs is essentially equal, situated between 22 and $24 \mu \mathrm{g} \mathrm{mL}^{-1}$. This evidence can suggest that both protein and carbohydrate coatings enable a similar mode of action against $X a c$ regardless of morphology and size of the nanoparticles. Thus, this study not only provides a comparison of distinct biomolecule coatings on nanoparticle properties using the same starting material but also presents a prospective method of citrus canker control using orange waste for the sustainable production of AgNPs.

\section{Acknowledgments}

The authors gratefully acknowledge FAPESP, grant number: 2015/12534-5, for the scholarship for Barros. The authors would like to thank the Mass Spectrometry Group from the Brazilian Biosciences National Laboratory for UPLCMS/MS analysis and for approving our proposal under number MAS-21531. The authors also thank the Multiuser Laboratory for Advanced Optical Spectroscopy (LMEOA/ IQ-UNICAMP, FAPESP grant number: 2009/54066-7). The authors also thank Mr Douglas Soares da Silva for conducting TEM analyses, as well as the Laboratório Multiusuários do Instituto de Física Gleb Wataghin (LAMULT) for the Raman scattering analysis using a Micro Raman XploRa spectrometer. Miss Danijela Stanisic is kindly acknowledged for her help in DLS measurements during the Or-AgNPs stability tests.

\section{Author contributions}

CHNB performed experiments and contributed to the article writing. GCFC and WM performed experiments. LT contributed to the project planning, execution, and article writing. All authors contributed toward data analysis, drafting and critically revising the paper, gave final approval of the version to be published, and agree to be accountable for all aspects of the work.

\section{Disclosure}

The authors report no conflicts of interest in this work.

\section{References}

1. Kiran GS, Dhasayan A, Lipton AN, Selvin J, Arasu MV, Al-Dhabi NA. Melanin-templated rapid synthesis of silver nanostructures. J Nanobiotechnol. 2014;12:18.

2. Lee HV, Hamid SB, Zain SK. Conversion of lignocellulosic biomass to nanocellulose: structure and chemical process. Scientific World J. 2014;2014:1-20.

3. Tian D, Hu J, Bao J, Chandra RP, Saddler JN, Lu C. Lignin valorization: lignin nanoparticles as high-value bio-additive for multifunctional nanocomposites. Biotechnol Biofuels. 2017;10:19.

4. Singh K, Panghal M, Kadyan S, Chaudhary U, Yadav JP. Green silver nanoparticles of Phyllanthus amarus: as an antibacterial agent against multi drug resistant clinical isolates of Pseudomonas aeruginosa. J Nanobiotechnol. 2014;12:40.

5. Ahmed S, Ahmad M, Swami BL, Ikram S. A review on plants extract mediated synthesis of silver nanoparticles for antimicrobial applications: a green expertise. JAdv Res. 2016;7:17-28.

6. Duman F, Ocsoy I, Kup F. Chamomile flower extract-directed $\mathrm{CuO}$ nanoparticle formation for its antioxidant and DNA cleavage properties. Mater Sci Eng C. 2016;60:333-338.

7. Jewett MC, Patolsky P. Nanobiotechnology: synthetic biology meets materials science. Curr Opin Biotechnol. 2013;24:551-554.

8. Saenz C, Estevez AM. Utilización de residuos de la indústria de jugos de naranja como fuente de fibra dietética en la elaboraición de alimentos [Utilization of residues from the orange juice industry as a source of dietary fibers in processed food]. Arch Latinoam Nutr. 2007;57:186-191. Spanish. 
9. Romero-Lopez MR, Osorio-Diaz P, Bello-Perez LA, Tovar J, Bernardino-Nicanor A. Fiber concentrate from orange (Citrus sinensis L.) bagase: characterization and application as bakery product ingredient. Int J Mol Sci. 2011;12(4):2174-2186.

10. Barros Santos E, Madalossi N, Sigoli FA, Mazali IO. Silver nanoparticles: green synthesis, self-assembled nanostructures and their application as SERS substrates. New J Chem. 2015;39:2839-2846.

11. Awad M, Hendi A, Ortashi K, et al. Silver nanoparticles biogenic synthesized using an orange peel extract and their use as an anti-bacterial agent. Int J Phys Sci. 2014;9:34-40.

12. Vankar P, Shukla D. Biosynthesis of silver nanoparticles using lemon leaves extract and its application for antimicrobial finish on fabric. Appl Nanosci. 2012;2:163-168.

13. Augustine R, Kalarikkal N, Thomas S. A facile and rapid method for the black pepper leaf mediated green synthesis of silver nanoparticles and the antimicrobial study. Appl Nanosci. 2014;4:809-818.

14. Demirbas A, Welt B, Ocsoy I. Biosynthesis of red cabbage extract directed Ag NPs and their effect on the loss of antioxidant activity. Mater Lett. 2016;179:20-23.

15. Ocsoy I, Demirbas A, McLamore E, Altinsoy B, Ildize N, Baldemir A. Green synthesis with incorporated hydrothermal approaches for silver nanoparticles formation and enhanced antimicrobial activity against bacterial and fungal pathogens. J Mol Liq. 2017:238;263-269.

16. Medda S, Hajra A, Dey U, Bose P, Mondal NK. Biosynthesis of silver nanoparticles from Aloe vera leaf extract and antifungal activity against Rhizopus sp. and Aspergillus sp. Appl Nanosci. 2015;5:875-880.

17. Amooaghaie R, Saeri M, Azizi M. Synthesis, characterization and biocompatibility of silver nanoparticles synthesized from Nigella sativa leaf extract in comparison with chemical silver nanoparticles. Ecotoxicol Environ Saf. 2015;120:400-408.

18. Khan M, Khan M, Adil S, et al. Green synthesis of silver nanoparticles mediated by Pulicaria glutinosa extract. Int J Nanomed. 2013;8: 1507-1516.

19. Emmanuel R, Palanisamy S, Chen S, et al. Antimicrobial efficacy of green synthesized drug blended silver nanoparticles against dental caries and periodontal disease causing microorganisms. Mater Sci Eng C. 2015;56:374-379.

20. Prakash P, Gnanaprakasam P, Emmanuel R, Arokiyaraj S, Saravanan M. Green synthesis of silver nanoparticles from leaf extract of Mimusops elengi, Linn. for enhanced antibacterial activity against multi drug resistant clinical isolates. Colloids Surf B. 2013:108;255-259.

21. Dhand V, Soumya L, Bharadwaj S, Chakra S, Bhatt D, Sreedhar B. Green synthesis of silver nanoparticles using Coffea arabica seed extract and its antibacterial activity. Mat Sci Eng C. 2016;58:36-43.

22. Karatoprak G, Aydin G, Altinsoy B, Altinkaynak C, Koşar M, Ocsoy I. The Effect of Pelargonium endlicherianum Fenzl. root extracts on formation of nanoparticles and their antimicrobial activities. Enzyme Microb Technol. 2017;97:21-26.

23. Akhtar M, Panwar J, Yun Y. Biogenic synthesis of metallic nanoparticles by plant extracts. ACS Sustainable Chem Eng. 2013;1:591-602.

24. Ballottin D, Fulaz S, Cabrini F, et al. Antimicrobial textiles: biogenic silver nanoparticles against Candida and Xanthomonas. Mater Sci Eng C Mater Biol Appl. 2017;75:582-589.

25. Ballottin D, Fulaz S, Souza ML, et al. Elucidating protein involvement in the stabilization of the biogenic silver nanoparticles. Nanoscale Res Lett. 2016;11:1-9.

26. Durán N, Silveira C, Durán M, Martinez DST. Silver nanoparticle protein corona and toxicity: a mini-review. J Nanobiotechnol. 2015;13:55.

27. Wen Y, Geitner NK, Chen R, et al. Binding of cytoskeletal proteins with silver nanoparticles. RSC Adv. 2013;3:22002-22007.

28. Lesniak A, Fenaroli F, Monopoli M, Åberg C, Dawson KA, Salvati A. Effects of the presence or absence of a protein corona on silica nanoparticle uptake and impact on cells. ACS Nano. 2012;6:5845-5857.

29. Garza-Navarro M, Aguirre-Rosales J, Llanas-Vázquez E, MorenoCortez IE, Torres-Castro A, González-González V. Totally ecofriendly synthesis of silver nanoparticles from aqueous dissolutions of polysaccharides. Int J Polym Sci. 2013;2013:1-8.
30. Sanyasi S, Majhi R, Kumar S, et al. Polysaccharide-capped silver Nanoparticles inhibit biofilm formation and eliminate multidrugresistant bacteria by disrupting bacterial cytoskeleton with reduced cytotoxicity towards mammalian cells. Sci Rep. 2016;6:1-16.

31. Sathiyanarayanan G, Seghal Kiran G, Selvin J. Synthesis of silver nanoparticles by polysaccharide bioflocculant produced from marine Bacillus subtilis MSBN17. Colloids Surf B. 2013;102:13-20.

32. Vasquez R, Apostol J, Leon J, et al. Polysaccharide-mediated green synthesis of silver nanoparticles from Sargassum siliquosum J.G. Agardh: assessment of toxicity and hepatoprotective activity. Open Nano. 2016;1:16-24.

33. Lokanathan AR, Uddin KM, Rojas OJ, Laine J. Cellulose nanocrystalmediated synthesis of silver nanoparticles: role of sulfate groups in nucleation phenomena. Biomacromolecules. 2014;15:373-379.

34. Mariño M, Lopes da Silva L, Durán N, Tasic L. Enhanced materials from nature: nanocellulose from citrus waste. Molecules. 2015;20(4):5908-5923.

35. Li N, Huang L, Liu L, Li D, Dai S, Deng Z. The relationship between PthA expression and the pathogenicity of Xanthomonas axonopodis pv. citri. Mol Biol Rep. 2014;41(12):967-975.

36. Tasic L, Borin PF, Khater LC, Ramos CH. Cloning and characterization of three hypothetical secretion chaperone proteins from Xanthomonas axonopodis pv. citri. Protein Expr Purif. 2007;53(2):363-369.

37. Ikan R. Natural Products: A Laboratory Guide. San Diego, CA: Academic Press; 1991.

38. Aragão AZB, Belloni M, Simabuco FM, et al. Novel processed form of syndecan-1 shed from SCC-9 cells play a role in cell migration. PLoS One. 2012;7(8):e43571.

39. Sierra JA, Vanoni CR, Tumelero MA, et al. Biogenic approaches using citrus extracts for the synthesis of metal nanoparticles: the role of flavonoids in gold reduction and stabilization. New J Chem. 2016;40:1420-1429.

40. Stephen A, Seethalakshmi S. Phytochemical synthesis and preliminary characterization of silver nanoparticles using Hesperidin. J Nanosci. 2013:2013:1-6.

41. Sahu N, Soni D, Chandrashekhar B, et al. Synthesis of silver nanoparticles using flavonoids: hesperidin, naringin and diosmin, and their antibacterial effects and cytotoxicity. Int Nano Lett. 2016;6:173-181.

42. Mukherjee P, Roy M, Mandal BP, et al. Green synthesis of highly stabilized nanocrystalline silver particles by a non-pathogenic and agriculturally important fungus $T$. asperellum. Nanotechnology. 2008;19(7):075103.

43. Picoli SU, Durán M, Andrade PF, Duran N. Silver nanoparticles/silver chloride $(\mathrm{Ag} / \mathrm{AgCl})$ synthesized from Fusarium oxysporum acting against Klebsiella pneumouniae carbapenemase (KPC) and extended spectrum beta-lactamase (ESBL). Front Nanosci Nanotech. 2016;2:107-110.

44. Durán N, Nakazato G, Seabra AB. Antimicrobial activity of biogenic silver nanoparticles, and silver chloride nanoparticles: an overview and comments. Appl Microbiol Biotechnol. 2016;100:6555-6570.

45. Barth A. Infrared spectroscopy of proteins. Biochim Biophys Acta. 2007;1767:1073-1101.

46. Dollish FR. Characteristic Raman Frequencies of Organic Compounds. New York, NY: Wiley \& Sons; 1974.

47. Huang GG, Han XX, Hossain MK, Ozaki Y. Development of a heat-induced surface-enhanced Raman scattering sensing method for rapid detection of glutathione in aqueous solutions. Anal Chem. 2009;81(14):5881-5888.

48. Rygula A, Majzner K, Marzec KM, Kaczor A, Pilarczyk M, Baranska M. Raman spectroscopy of proteins: a review. J Raman Spectrosc. 2013;44:1061-1076.

49. Çaliskan M. Germin, an oxalate oxidase, has a function in many aspects of plant life. Turk J Biol. 2000;24:717-724.

50. Souza AA, Takita MA, Colleta-Filho HD, et al. Analysis of expressed sequence tags from Citrus sinensis L. Osbeck infected with Xylella fastidiosa. Genet Mol Biol. 2007;30:957-964.

51. Edwards R, Dixon DP, Walbot, V. Plant glutathione S-transferases: enzymes with multiple functions in sickness and in health. Trends Plant Sci. 2000;5:193-198. 
52. Lo Piero AR, Puglisi I, Petrone G. Gene isolation, analysis of expression, and in vitro synthesis of glutathione S-transferase from orange fruit (Citrus sinensis L. [Osbeck]). JAgric Food Chem. 2006;54:9227-9233.

53. Darabi M, Seddigh S. Bioinformatic characterization of aspartic protease (AP) enzyme in seed plants. Plant Syst Evol. 2015;301:2399-2417.

54. Simões I, Faro C. Structure and function of plant aspartic proteinases. Eur J Biochem. 2004;271:2067-2075.

55. Rawlings ND, Barrett AJ. Families of aspartic peptidases, and those of unknown catalytic mechanism. Methods Enzymol. 1995;248:105-120.

56. Garcia-Marttnez JL, Moreno J. Proteolysis of ribiilose-1,5-bisphosphate carboxylase/oxygenase in Citrus leaf extracts. Physiol Plant. 1986;66:377-383.

57. Prabhu S, Poulose EK. Silver nanoparticles: mechanism of antimicrobial action, synthesis, medical applications, and toxicity effects. Int Nano Lett. 2012;2:1-10.

58. Le Ouay B, Stellacci F. Antibacterial activity of silver nanoparticles: a surface science insight. Nano Today. 2015;10:339-354.

59. Bertoli F, Garry D, Monopoli M, Salvati A, Dawson KA. The intracellular destiny of the protein corona: a study on its cellular Internalization and evolution. ACS Nano. 2016:10;10471-10479.

60. Li WR, Xie XB, Shi QS, Zeng HY, Ou-Yang YS, Chen YB. Antibacterial activity and mechanism of silver nanoparticles on Escherichia coli. Appl Microbiol Biotechnol. 2010;85:1115-1122.
61. Sondi I, Salopek-Sondi B. Silver nanoparticles as antimicrobial agent: a case study on $E$. coli as a model for Gram-negative bacteria. J Colloid Sci. 2004;275:177-182.

62. Feng QL, Chen GQ, Cui FZ, Cui FZ, Kim TN, Kim JO. A mechanistic study of the antibacterial effect of silver ions on Escherichia coli and Staphylococcus aureus. J Biomed Mater Res. 2000;52:662-668.

63. Ocsoy I, Gulbakan B, Chen T, et al. DNA-Guided-Metal nanoparticle formation on graphene oxide surface. Adv Mater. 2013:25;2319-2325.

64. Ocsoy I, Paret M, Ocsoy M, et al. Nanotechnology in plant disease management: DNA-directed silver nanoparticles on graphene oxide as an antibacterial against Xanthomonas perforans. ACS Nano. 2013;7:8972-8980.

65. Shetty S, Mahin-Syed-Ismail P, Varghese S, et al. Antimicrobial effects of Citrus sinensis peel extracts against dental caries bacteria: an in vitro study. J Clin Exp Dent. 2016;8(1):e70-e77.

66. Corciova A, Ciobanu C, Poiata A, et al. Antibacterial and antioxidant properties of hesperidin: $\beta$-cyclodextrin complexes obtained by different techniques. J Incl Phenom Macrocycl Chem, 2015:81;71-84.

67. Bevilacqua A, Corbo M, Sinigaglia M. In vitro evaluation of the antimicrobial activity of eugenol, limonene, and Citrus extract against bacteria and yeasts, representative of the spoiling microflora of fruit juices. J Food Prot, 2010;73:888-894. 


\section{Supplementary materials}

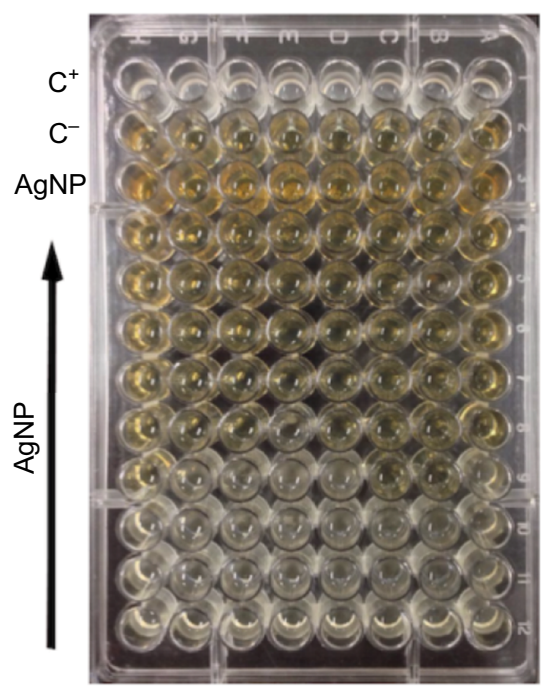

Figure SI Example of MIC assay after incubation for $48 \mathrm{~h}$ at $35^{\circ} \mathrm{C}$ using fresh peel extract AgNPs.

Notes: The first row is a positive control, containing culture medium and the bacteria; the second row is a negative control, containing culture medium and $\mathrm{AgNPs}$ suspension; the third row contains only the stock AgNPs suspension and, from rows 12 to 4, there is a positive gradient of AgNPs concentration.

Abbreviations: AgNPs, silver nanoparticles; MIC, minimum inhibitory concentration.
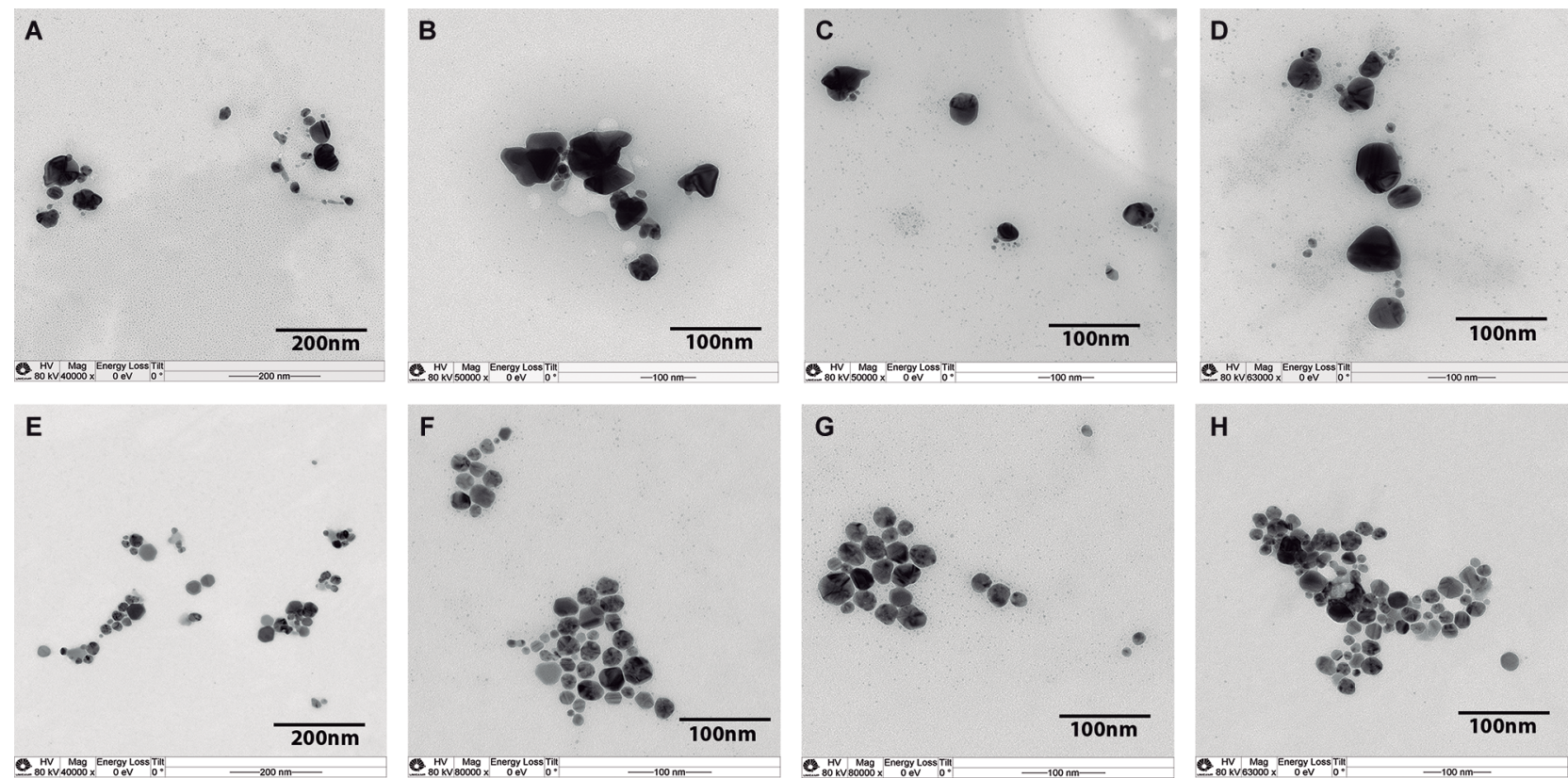

Figure S2 TEM micrographs of AgNPs: (A-D) correspond to fresh orange peel extract AgNPs; (E-H) correspond to hesperidin and nanocellulose produced AgNPs. Abbreviations: $\mathrm{AgNPs}$, silver nanoparticles; TEM, transmission electron microscopy. 
Nanotechnology, Science and Applications is an international, peer-reviewed, open access journal that focuses on the science of nanotechnology in a wide range of industrial and academic applications. It is characterized by the rapid reporting across all sectors, including engineering, optics, bio-medicine, cosmetics, textiles, resource sustainability and science. Applied research into nano-materials, particles, nano-structures and fabrication, diagnostics and analytics, drug delivery and toxicology constitute the primary direction of the journal. The manuscrip management system is completely online and includes a very quick and fair peer-review system, which is all easy to use. Visit http://www.dovepress.com/ testimonials.php to read real quotes from published authors. 